\title{
TACKLING THE IMPACT OF THE COVID-19 PANDEMIC IN ECONOMY AND LABOUR - A Case Studey of SERbia Regulation
}

\author{
Accepted \\ 27. 07. 2021 \\ Revised \\ 23. 08.2021 \\ Published \\ 29. 10. 2021 \\ Ranko P. Sovilj \& Sanja N. Stojković Zlatanović \\ Institute of Social Sciences, Belgrade, Serbia. \\ E-mail: soviljpeca@gmail.com, sanjazlatanovic1@gmail.com \\ CORRESPONDING AUTHOR \\ soviljpeca@gmail.com
}

Keywords

Covid-19

pandemic,

state

aid,

set of

socio-economic

measures,

economy and

labour

framework,

Serbian

regulation

\begin{abstract}
The paper deals with the foundation of policy and legal national framework addresses, particularly, the adequacy of state measures in the areas of economy and labour as a response to Covid-19 pandemic. The aim is, by analyzing recent soft law documents of international organizations and the introduced models of comparative policy practices, to make critical considerations regarding the policy responses in the crises conducted by the Serbian Government. The humancentered, holistic, and integrated approach had been applied accompanied by the legal normative and comparative methods. Putting the current Serbian regulation in the context of the international area of policy emergency response, the territorial approach has been determined as most applicable, accompanied by the spatial coverage to the most vulnerable sectors. Government stimulation policy in the area of economy and employment in the Covid-19 crisis must be based on the rapid and reliable assessment of the impact of a lockdown or trade and job restrictions as on medium to longer-term recovery strategies of trade and employment. The principle of global and national solidarity, public-private partnership are core elements that need to be incorporated in the legal framework to tackle the impact of the Covid-19 pandemics in the economy and labour.
\end{abstract}




\section{$1 \quad$ Introduction}

The Covid-19 pandemic that spread throughout the world has caused both a massive health crisis and devastation to the global economy and the economies of individual countries (Vasić, 2020: 4). Health measures introduced in order to control the spread of coronavirus caused economic lockdown leading countries to record negative GDP growth. This, in turn, alarmed many national governments, inducing them to adopt economic recovery measures to help mitigate the overall territorial effects of the pandemic.

The key considerations for the policymakers that have emerged are: Could we make projections for the national recovery based on current economic response measures considering their effectiveness? (Milić \& Anđelković, 2021: 381). Particularly, basic economic issues addressed by the supranational and national policymakers are presented as follows: How, and how far and fast, will the economic damage spread? How bad will it get? How long will the damage last? What are the mechanisms of economic contagion? And, above all, what can governments do about it? (Baldwin \& Weder di Mauro, 2020: 1). Furthermore, the economic damage, certainly, would reinforce social inequality both globally and locally, raising the question, which societal model do policymakers want to create for future generations? The optimal model is one that will promote long-term economic, social, and environmental sustainability benefits in order to restart the national economy after the crisis.

The pandemic has been a huge shock to the international, European and national economies. How did a health crisis translate to an economic crisis? Why did the spread of the coronavirus bring the global economy to its knees? The answers lie in two ways in which coronavirus stifled economic activities. Primarily, the spread of the virus encouraged social distancing, which in turn led to the shutdown of financial markets, corporate offices, businesses and events. All economic sectors have been effected by the disruption in global supply chains, which resulted both in an increase in the unemployment rate as well as in the number of aid seekers. Secondly, the exponential rate at which the virus was spreading, and the heightened uncertainty about how bad the situation could get, led to flight to safety in consumption and investment among consumers, investors and international trade partners (Peterson \& Thankom, 2020: 1). 
The ultimate duration of the supply-shock depends upon the virus's lethality and is thus highly uncertain. In this regard, some economic forecasters considered the extreme scenarios (extreme in the sense that they include death rates outside the ranges seen in the last half-century) inferring that the shock could much more directly and continually reduce employment by decreasing the labour supply due to deaths. However, the reality seems to be somewhere in the middle of both of these extremely negative and optimistic scenarios (Baldwin \& Weder di Mauro, 2020: 14).

The Covid-19 crisis has massively altered some pre-existing trends. The neoliberal economic doctrine, which has been dominant on a global level for more than forty years, is based on the postulates of freedom of choice, individual liberties and economic freedom (in the form of a free market with minimal state role) as well. During the pandemic, the economic sector suffered great losses on a global level. The governments reacted by allocating huge funds to help the economy, contrary to what proponents of neoliberalism typically claim, i.e., that the market will recover naturally (Milić \& Anđelković 2021: 381-382).

Considering the experience of the financial crisis from 2008, the unexpectedness and lack of wealth caused the adoption of non-standard economic measures that had no basis in any particular theoretical framework (Tasić, 2020: 86). Consequently, the impact of the Covid-19 pandemic on financial systems will depend on: 1. how much further the coronavirus will spread across the world and its affect on economic activity; 2. fiscal and monetary policy reactions to the shock, and 3. regulatory responses to the possible collapse of the banking system (Beck, 2020: 73). Nevertheless, since the Covid-19 is a truly global shock, international coordination is essential, particularly in the spheres of regulatory and economic policy, healthcare and science, along with containment and mitigation efforts as well. Therefore, it is crucial for policymakers to conduct careful assessments of the effectiveness of socioeconomic measures taken to mitigate the consequences caused by the spread of coronavirus (Loayza \& Pennings, 2020: 1). Hence, the aim of this paper is to analyse the justification for socio-economic measures adopted in Serbia, both from the theoretical standpoint as well as from the practical policy standpoint, i.e., the examples of good comparative practices. The application of the territory sensitive approach, the so-called place-based approach, multi-level coordination, both at the national and supranational levels, and the identification of vulnerable groups need 
to be considered as important factors for managing the crisis across levels of government (OECD, The territorial impact of Covid 19, November 2020).

\section{Normative framework for the adoption a set of socio-economic measures to mitigate the effects of Covid-19 pandemic}

There is no doubt that the precipitous decline in economic activity led to a deepening of economic problems, an increase in the unemployment rate, falling living standards, and potentially an increase in both poverty and inequality. According to IMF forecasts, the overlooked fall in the world economy in 2020 will be weaker by half compared to the 1930s when the economy dipped ten percent (Marjanović \& Đukić, 2020: 92).

In order to provide the emergency support to businesses and workers that are facing the catastrophic losses during the pandemic, as well as to increase the capacity of their health systems, the European Union Member States adopted a set of recovery measures. The emergency measures included financial support to ensure the liquidity of companies, initiatives for development of treatments and vaccines, and stimulations of the labour market designed to safeguard employment and to protect jobs. In addition, the funds included support in the form of direct and indirect health care costs related to the pandemic (Milić \& Anđelković, 2021: 382).

During the crisis, the governments of EU Member States set aside funds for the aid and recovery of companies with strategic value for the countrys' economy (such as national air transport companies, national electricity distribution companies, etc.), either via direct financing or via guarantees for repaying loans to commercial creditors. Even under such arrangements, countries mostly insist on improving environmental and other business standards and meeting long-term goals of sustainable development, in accordance with the national strategies and international agreements. (Vasić, 2020: 5). The set of support measures that have been implemented so far in different countries, generally, involve direct state grants for vulnerable economic sectors, different guarantee schemes by the governments and international institutions, as well as initiatives for the implementation of temporary delays in payments, a.k.a. moratorium in the repayment of obligations (Vasić, 2020: $5)$. 
The European Commission set aside 750 billion euros for economic recovery, of which 390 billion euros are intended for grants and 360 billion euros in loans. Member States were required to prepare an economic recovery plan in order to receive support from the recovery fund. States are required to precisely define the reform and investment programs by 2026, including the objectives and estimated costs, challenges and priorities of the recovery plan that they should adhere to, such as: job creation, economic and social resilience of the Member States and GDP growth (Milić \& Anđelković, 2021: 386).

The question arises whether the support measures taken to help the economy and workers are in accordance with the regulations on state aid control. In accordance with the EU regulations on state aid control, Member States may invoke Article 107 of the Treaty on the Functioning of the European Union - TFEU. Save as otherwise provided in the Treaties, any aid granted by a Member State or through State resources, in any form whatsoever, which distorts or threatens to distort competition by favouring certain undertakings or the production of certain goods shall, in so far as it affects trade between Member States, be considered incompatible with the internal market. The following will be compatible with the internal market: (a) aid having a social character, granted to individual consumers, provided that such aid is granted without discrimination related to the origin of the products concerned; (b) aid to make good the damage caused by natural disasters or exceptional occurrences (The Treaty on the Functioning of the European Union, 2016, Article. 107). This provision provides a legal basis for Member States to act quickly and efficiently and to grant assistance to companies and workers faced with economic difficulties due to the outbreak of Covid-19. In addition, Article 107(2) provides a legal basis for the Commission to approve state aid for damages caused by natural disasters or other emergencies. The first case of granting state aid under Article 107(2), pertaining to the outbreak of the Covid-19 pandemic, was the approved aid scheme for the cancellation of events in Denmark. According to this scheme, the organizers of large events will be compensated for losses due to the cancellation or postponement of these events due to the outbreak of the crisis caused by the Covid-19 (Gecić Law, 2020). In addition to measures that are approved under the normative regime of state aid, the Member States have at their disposal a series of measures that are not considered state aid within the meaning of EU regulations and are not subject to registration, such as the allocation of financial support directly to consumers (for example compensation costs for canceled services or tickets, in case that the same 
compensation is not provided by service providers), coverage of paid salaries for employees, exemption from the obligation to pay VAT, income tax and social contributions (Gecić Law, 2020).

The State aid control system in the Republic of Serbia ${ }^{1}$ primarily was established in 2010 by the adoption of the Law on State Aid Control ${ }^{2}$ and two bylaws: the Regulation on the rules for state aid granting ${ }^{3}$ and the Regulation on rules and procedure for state aid granting. ${ }^{4}$ Furthermore, for the purpose of drafting annual reports on granted state aid, the Rulebook on methodology for drafting annual reports on granted state aid ${ }^{5}$ was adopted in 2011.

On October 10, 2019 the Serbian National Assembly enacted the new Law on State Aid Control, which became effective on January 1, 2020. The new legislation was drafted with a view to harmonization with the European Union's acquis in this field. It remedies, at least to a significant extent, the shortcomings of the existing state aid law. The definition of selectivity has been extended from favouring a certain competitor to favouring a competitor or certain goods and/or services. Moreover, in order to constitute state aid, a measure must not only affect competition, but it must also have an EU dimension reflected in the requirement that the measure must affect the trade between Serbia and the EU Member States (BDK advokati, 2020).

\footnotetext{
1 The establishment of a strong state aid system in the Republic of Serbia, in accordance with the rules applicable for all Member States, which implies harmonizing the national legislation in this field, creating good state aid schemes, strengthening the capacities of state aid grantors and the bodies that control state aid granting, will largely benefit economic operators doing business in the Republic of Serbia, because appropriate state aid control authorizes strengthening free competition, establishing better market conditions and determining the manner of granting subsidies and other state aid types to certain economic operators. Hence, this scheme will help prevent putting certain economic operators in a more favourable position to the expense of others and otherwise help level the playing field for all market participants, which will in turn incentivize new companies to enter into and stay in the market of the Republic of Serbia and enable their economic development. Finally, consumers, that is, the citizens of the Republic of Serbia, will ultimately benefit as well (Commission for State Aid Control of the Republic of Serbia, 2020).

${ }^{2}$ Law on State Aid Control, Official Gazette of the Republic of Serbia, no. 51/09.

${ }^{3}$ Regulation on the Rules for State Aid Granting, Official Gaztte of the Republic of Serbia, no. 13/10, 100/11, 91/12, $37 / 13,97 / 13$ and $119 / 14$.

${ }^{4}$ Regulation on the Rules and Procedure for State Aid Granting, Official Gazette of the Republic of Serbia, no. 13/10.

${ }^{5}$ Rulebook on Methodology for Drafting Annual Report on Granted State Aid, Official Gazette of the Republic of Serbia, no. $3 / 11$.
} 
The new law introduces the notions of "compatible" and "incompatible" state aid. The Law further lists the forms of state aid that are always considered compatible, mirroring Article 107(2) of the TFEU, as well as those that may be considered compatible if they meet one of the prescribed criteria which are broadly in accordance with Article 107(3) TFEU. State aid which is assessed as incompatible is disallowed. Respectively, the new Law on State Aid Control stipulates that: (1) aid of a social nature, intended for consumers, as well as (2) aid granted to eliminate damage caused by natural disasters or in other emergency situations, shall be considered as compatible aid (Law on State Aid Control, 2019, Article 5).

Finally, a comprehensive comparative analysis of the various economic policies adopted by almost all countries of the world shows that they consist of an economic set of measures including fiscal measures, monetary measures and exchange rate measures. Monetary policies adopted by countries usually consist of supporting liquidity to banks, while measures of fiscal policies include transfers to households and businesses, the expansion of social security benefits and resources for the healthcare system (Marjanović \& Đukić, 2020: 94). The conclusion is that economic policy alone cannot end the crisis, but it has a key role: protecting the livelihoods of people, preserving jobs and strengthening social safety nets.

\section{Economic Support Measures as a Response to Covid-19 crisis - Regulatory framework in Serbia}

Bearing in mind that the Republic of Serbia is a small, open economy, and that international factors, particularly in the European Union, significantly affect national economic flows, the impact of the crisis caused by Covid-19 has been asymmetric, with some economic sectors being hit harder by the pandemic than others. Instead of the forecasted GDP growth of four percent, there was a regression. This included a rise in unemployment, the growth of the fiscal deficit and debt reduction in foreign capital inflows. The long-term effects of the epidemic on the economy and employment will depend not only on the length and intensity of the crisis caused by Covid-19, but also on the economic and fiscal policy measures that the Government will implement during the year (NALED, 2020: 2). In an effort to respond to the evolving situation, the Serbian government has taken the appropriate measures, the main objectives of which have been to preserve economic stability with the support of micro, small and medium-sized enterprises in the private sector (Marjanović \& 
Đukić, 2020: 91). Therefore, the aim of this paper is to analyse the set of adopted economic measures to mitigate the consequences of Covid-19.

In order to mitigate against the detrimental effects of the pandemic, the Ministry of Finance and the National Bank of Serbia (hereinafter NBS), each in their respective jurisdiction, have adopted a set of measures (Martin, 2020: 70). The program of economic measures for supporting the national economy enabled certain fiscal benefits and direct budget funding for legal entities in the private sector, as well as the disbursement of one-off financial aid of 100 euros in dinar equivalent to all adult citizens of the Republic of Serbia (Vasić, 2020: 5).

The measures taken to mitigate the consequences of the crisis caused by Covid-19 are aimed at businesses registered in the Republic of Serbia which are not part of the financial sector, i.e., are not the beneficiaries of the public sector (Marjanović \& Đukić, 2020: 103). The entrepreneurs who have registered a temporary cessation of activities at the earliest on March 15, 2020, i.e., on the day Serbia declared a state of emergency, as well as associations and other non-profit organizations, can avail themselves of the benefits of this program, so long as they are not on the list of users of public funds (NALED, 2020: 8). The program, worth EUR 5.1 billion or RSD 608.3 billion, includes tax policy measures, direct assistance to the private sector, measures to preserve liquidity for the private sector and other measures. The aim of the program is to help the economy, especially the private sector, but also the workers to preserve their jobs (Martin, 2020: 78).

Since the beginning of the pandemic and the introduction of the state of emergency, 67.000 employees have worked from home, while 168 manufacturing companies have suspended production. Infrastructure and transport have suffered losses amounting to over 110 million euros. The tourism sector lost about 2.7 million euros between March and the first half of April 2020. About 85 percent of small and medium enterprises are projected to be negatively impacted by the pandemic (Milić \& Anđelković, 2021: 390). Since the beginning of the pandemic and the introduction of the state of emergency, the services and industry sectors have witnessed a steady decline in value, while agriculture has recorded positive growth. However, there are some services sectors that have recorded growth, such as information and communication technologies. It is interesting that the construction sector recorded growth; the value added in this sector was 0.1 percent (Milić \& Anđelković, 2021: 
392). Following the example of developed countries, the Government of the Republic of Serbia has adopted a set of economic measures to help the economy and reduce the negative effects caused by the Covid-19 pandemic. The program contained four groups of economic measures.

\subsection{Tax policy measures}

Given that one of the biggest problems encountered by companies during the Covid-19 pandemic was the difficulties in fulfilling their tax liabilities, the first set of economic measures was directly linked to tax policy. Accordingly, the focus was on tax relief, i.e., postponing the payment of overdue tax liabilities (Marjanović \& Đukić, 2020: 97). The first set of measures relates to the deferral of taxes and contributions for the duration of the state of emergency with the payment of those liabilities beginning at the earliest in 2021, as well as the deferral of the payment of income taxes in the second quarter. The objectives of this measure are to provide the economy with tax relief and preserve liquidity, both of which are significantly endangered during a state of emergency, as well as to preserve jobs (Martin, 2020: 78).

The entrepreneur, entrepreneur lump, farmers, micro, small and medium-sized enterprises in the private sector have right to the payment of grants from the budget. All of these firms can avail themselves of the benefits of this regulation if they have not dismissed more than ten percent of their employees since March 15, 2020 (Marjanović \& Đukić, 2020: 98). If there is a breach of conditions, the grant beneficiary is obliged to pay all obligations that were deferred with interest, which runs from the date of maturity of each individual obligation, within five days of the loss of rights. The main objective of these measures is to increase the liquidity of all enterprises in the business (private) sector.

\subsection{Direct support to business sector}

Since the Covid-19 pandemic greatly affected the liquidity of the business sector, the second set of economic measures, which took the form of direct payments, were aimed at helping enterprises and companies, which are reflected in the payment of three minimum wages. This set of economic measures was designed to provide direct support to entrepreneurs, micro, small and medium-sized enterprises through 
the provision of three minimum wages, as well as large private sector enterprises for which the payment of 50 percent of the net minimum wage is planned during the state of emergency. In order to qualify for direct support, the requestor must have a dedicated account with the selected bank. The objective of this measure is to preserve jobs. To qualify for this relief, the requesting employer must not reduce the number of employees compared to March 15, 2020. This is exactly how the objective of such a measure stated in the text is achieved in the context of preserving the existing level of employment. The employer has the prerogative to decide whether to use the direct support of the state as a wage supplement or whether it will form part of the salary (Martin, 2020: 78).

Observing the second set of economic measures, the government has made a clear distinction between small and medium enterprises on the one side, and large enterprises, on the other. This was done mainly due to differences in the economic strength of taxpayers, given the assumption that economic entities classified as large companies have greater economic strength compared to entrepreneurs, micro, small and medium-sized enterprises. This is exactly the reason why these enterprises receive financial compensation in the amount of the net minimum wage for each employee (Marjanović \& Đukić, 2020: 99). Regarding large companies, the government has assumed the obligation to pay part of the salary for employees who are still employed by the employer, but due to the reduced volume of work are not employed during the crisis. In this way, the government intends to encourage large employers not to dismiss employees, while in the case of other business entities (entrepreneurs, micro, small and medium-sized enterprises), the government aims to provide assistance in maintaining liquidity in order for these entities to continue their business activities (Marjanović \& Đukić, 2020: 99). The objective of the government measures is to stimulate large companies to maintain the existing level of employment. At the same time, the government will endeavor to further strengthen the liquidity of entrepreneurs, small, micro and medium-sized enterprises with a larger scope of rights, all with the aim of maintaining business activities during the pandemic. 


\subsection{Measures to preserve companies' liquidity}

In April 2020, the Serbian government adopted a Decree on establishing the program of financial support to enterprises to maintain liquidity and working capital in difficult economic conditions due to the Covid-19 pandemic caused by SARS$\mathrm{CoV}-2$. The third set of economic measures relates to providing liquidity to the economy through loans from the Development Fund of the Republic of Serbia and a guarantee scheme for supporting the economy through banks. The objective of these measures is to provide liquidity to the economy for the duration of the Covid19 pandemic and to repair the after-effects. Through the Development Fund, companies can receive a loan for a period of 36 months, which includes a grace period of up to twelve months, an interest rate of one percent per annum and repayment of the loan in monthly installments. The maximum loan amount is up to RSD 10 million for entrepreneurs and micro-enterprises, up to RSD 40 million for small legal entities and up to RSD 120 million for medium-sized legal entities (Martin, 2020: 79).

\subsection{Direct support to all adult citizens}

At the beginning of April 2020, the Government of the Republic of Serbia passed the Decree on fiscal benefits and direct benefits to economic entities in the private sector and financial assistance to citizens. The goal of this Decree was to assist in mitigating the economic consequences caused by the Covid-19 pandemic. These measures include a moratorium on the payment of dividends by the end of the previous year, except for public companies, as well as the payment of 100 euros to all adult citizens. While the measures aimed at strengthening the economy are positively assessed, budget-justified and well-structured, the payment of 100 euros to all adults, according to the Fiscal Council, is a completely inappropriate measure. The Fiscal Council, in its analysis of the "Assessment of the Anti-Crisis Program of Economic Measures", emphasizes that it is not a measure that will stimulate economic growth, because it would mean that the low paying power of the population, not the pandemic of Covid-19, is the cause of the economic crisis, which is not true. Additionally, the proposed measure is not of a social character either, since the same amount will be paid to all adult citizens of Serbia, and not just to the financially struggling population (Martin, 2020: 80). 


\subsection{Monetary policy measures of the National Bank of Serbia}

The National Bank of Serbia (NBS) adopted appropriate interim measures in order to preserve the financial system. The NBS lowered the key reference rate to support credit and economic growth, and then provided additional dinar and foreign currency liquidity to the banking sector, through EUR/RSD swaps and repo auctions, and made decisions prescribing a moratorium on debt payments (Martin, 2020: 70).

The NBS justified this decision as a timely and adequate response to the increased uncertainty in the international environment caused by the spread of the Covid-19, which is in accordance with the activities undertaken by other central banks in the world (Martin, 2020: 71). ${ }^{6}$

The following monetary policy measure applied by the NBS is designed to provide dinar and foreign currency liquidity to the banking sector in a state of emergency in the Republic of Serbia, due to the spread of the Covid-19. This was accomplished by applying additional EUR/RSD swap auctions and repo operations (Martin, 2020: 72). An additional instrument for providing dinar liquidity to the banking system is the repurchase of dinar government securities. This instrument can be used by banks that have dinar government securities in their portfolio, which represent collateral to secure dinar liquidity (Martin, 2020: 73).

At an extraordinary meeting of the Executive Board, held on March 12, 2020, the NBS adopted the Decisions prescribing a moratorium on debt payments, the Decision on Temporary Measures for Preserving Financial System Stability and the Decision on Temporary Measures for Lessors Aimed at Preserving Financial System Stability. The objectives of the adopted measures were to preserve and further strengthen the stability of the financial system and to protect all debtors during an emergency caused by Covid-19 pandemic (Martin, 2020: 74). This set of decisions

\footnotetext{
${ }^{6}$ Given that the virus originated in China and first affected its economy, the Central Bank of China is an exception, given that it followed the pandemic without additional monetary interventions. All other major economies had specific incentive programs that caused a great increase in the quantity of primary money. Between March and June 2020, the monetary base of the Federal Reserve System grew by approximately 50 percent, or $\$ 1.7$ trillion, thanks to securities purchase operations, before its growth stopped. The European Central Bank (ECB) reacted in a similar manner, increasing its monetary base by 1.6 trillion euros. However, to that amount at the European Central Bank should be added increased loans to banks through long-term repo operations, so in the case of the eurozone, we can talk about the total primary issue of over 3 billion euros previous year (Tasić, 2020: 87).
} 
was made to prevent the nonperforming loan (NPL) growth faced by Serbia's banking sector in the previous period.

The moratorium was accepted by 94 percent of citizens who have obligations towards banks, while fewer than six percent explicitly asked to continue their repayment. As many as 92.9 percent of companies opted for the moratorium, and 7.1 percent stated that they still want to pay their obligations (Martin, 2020: 75). The moratorium is anticipated for all debtors (sole proprietors, entrepreneurs, farmers and companies) that may accept the offer from a bank/lessor and it implies a suspension of debt payments for at least 90 days, i.e., for the duration of the emergency state declared due to the Covid-19 pandemic (Marjanović \& Đukić, 2020: 101). During this period, debtors will be relieved of the repayment of their obligations under loan and lease agreements.

The Decree on Amendments to General Revenues and Receipts, Expenditures and Expenses of the Budget of the Republic of Serbia for 2020, enacted in order to eliminate harmful consequences due to Covid-19 disease caused by the SARS-CoV2 virus, forecasts that a part of the economic measures should be financed not only from domestic and international commercial and multilateral loans, financial institutions and foreign governments, but also through the issuance of government securities (government bills and bonds on the domestic financial market in domestic and foreign currency) and from the proceeds from the issuance of Eurobonds (government securities issued on the international financial market in domestic and foreign currency). ${ }^{7}$ An additional source of financing for large companies could be the corporate bond market, which, under relatively favorable conditions, could raise the deficient funds on the national capital market and thus contribute to its further development. Collectively, these schemes should contribute to both preserving the previously achieved fiscal stability and ensuring the stability of public finance (Martin, 2020: 81).

7 The Decree on Amendments to General Revenues and Receipts, Expenditures and Expenses of the Budget of the Republic of Serbia for 2020 in order to eliminate harmful consequences due to Covid19 disease caused by SARS-CoV-2 virus, Official Gazette of the Republic of Serbia, no. 60/2020. 


\subsection{Direct support to the most vulnerable sectors of economy in 2021}

In the meantime, the Serbian government adopted two additional packages of measures to not only help bolster the national economy but to preserve jobs. As opposed to the first and second set of measures, the third set of measures, which were adopted in February 2021, impacts large companies that are also suffering huge losses in their businesses caused by the Covid-19 pandemic. A total of 1.5 million entrepreneurs and employees in micro, small, medium-sized enterprises and large companies will receive direct state support in the amount of one and a half minimum wages. Since the professional community criticized the foregoing measures on the grounds that not everyone was equally effected by the Covid-19 crisis, and that certain sectors of the economy are more effected than others, by adopting this set of measures the Serbian government has provided direct support for the most vulnerable sectors of the national economy. In addition to one-and-a-half minimum wages, support in the amount of another full minimum will be given to caterers, licensed tourist guides and companions, travel agencies, hotels resorts, car rental agencies, sector of passenger and road transport (namely, the hospitality sector). On the other hand, this package of measures does not include banks and other financial institutions. Additionally, this set of measures also includes financial assistance to all adult citizens, who will receive 60 euros. This measure will be implemented through two payments - in May and November 2021.

\section{Job retention support measures as a response to Covid-19 crisis in Serbia - Critical considerations}

The labour market impact and the impact on working conditions caused by the Covid-19 pandemic differ across countries, depending, primarily, on labour force characteristics and the structure of the labour market, specific institutional arrangements, as well as crisis response measures (Eichhorst, Marx \& Rinne, 2020: 375). Also, both the specific model adopted for employment protection coupled with the flexibility in employment arrangements introduced by the national labour legislation are of crucial importance for preserving jobs. 
The prevailing opinion in the literature is that the short-term consequences of the pandemic are the increase in the unemployment rate and decrease in the hours of work but without any significant impact on wages (Fana et al., 2020: 392). This viewpoint is questionable considering the joint Report of the International Labour Organization (ILO) and OECD regarding the pandemic's impact on jobs and income in G20 economies. The Report concludes that in some sectors such as airlines, retail and accommodation, food service, and textile and garment many workers, among them mostly women, had to accept wage reductions (ILO, 2020; OECD, 2020: 14). The long-term consequences are evidenced by the increase of inequality and poverty, particularly, among vulnerable social and labour groups i.e., young, older and low-skilled workers, ethnic minorities, women, migrants, selfemployed and all those working in non-standard/informal economies (Fana et al., 2020: 392).

Considering the uncertainty surrounding how long the pandemic will last, on the one side, and the overall impact of other related socio-economic measures, on the other, it is too early to provide an accurate assessment of the effectiveness of national labour measures. However, some assumptions can be made, in terms of the recommendations of the international organizations and best-practice models introduced in comparative policy and practice. According to the OECD assessment of the territorial impact of Covid-19, the impact is highly asymmetric within countries. Factors include the region, as well as the economic sector and population effected, so that the basic recommendation to policymakers is to apply the placedbased approach in defining and implementing the mitigation measures, specifically targeting the vulnerable areas, sectors and populations (OECD, 2020).

In Serbia, according to the Report of the impact of Covid-19 crisis in employment and labour - Focus on vulnerable populations (2021) that has been introduced by the Social Inclusion and Poverty Reduction Unit of the Government of the Republic of Serbia, the informal workers (usually those who do not have explicit, written contracts of employment, such that their employment is not subject to labour legislation, social security regulations, collective agreements, etc.) have been dominantly impacted by the crisis, particularly, in the period of state emergency. The sectors most impacted are those that presuppose personal contacts i.e., transport services, accommodation and retail, food services, other personal services, etc. (Udovički \& Medić, 2021: 55). The workers considered as vulnerable, such as women, young and older workers, as 
well as the low-skilled workers, are predominantly engaged in these sectors, so their vulnerability has been doubled (Udovički \& Medić, 2021: 55). Moreover, these workers are mostly those who have been working in the informal economy, and consequently they suffer from multiple vulnerabilities. Importantly, the impact of the crisis has been measured only in the private sector. The Report has not taken into consideration the workers in the public sector, who are mostly engaged by formal work contracts and considered highly protected by national labour legislation.

Compared to the comparative overview introduced in the reports of international organizations, particularly, the ILO and OECD, regarding the impacts of the pandemic in employment and labour, Serbia records a decrease in informal employment without significant effects on formal employment. Thus, the sectors and types of labour populations effected correspond to those reported in comparative practice. The reduction of wage and job loss, also, has been reported in the mentioned sectors and the work population i.e., primarily among informal workers, most of them being young workers and women. According to these findings, in Serbia the crisis has not significantly impacted the formal work sector where the decline in business activities in a period of state emergency (March to May 2020), increases gradually after the period, reaching its pre-crisis level (Udovički \& Medić, 2021: 16). Although there is no reliable data regarding informal employment, recovery to some extent has certainly happened (Udovički \& Medić, 2021: 16). In this regard, two kinds of government job retention support measures have been applied - the one targeting unincorporated businesses and micro, small, and medium-sized enterprises and one targeting large enterprises (ILO, 2020: 41). The first set of economic measures included the payment of the net minimum wage for each full-time worker employed in March, April and May of 2020, where all economic entities in the private sector were eligible for the support. The second, i.e., the employment retention measure targeting large enterprises, included the payment of 50 percent of the minimum wage for each employee who was obliged to take leave during the lockdown (state of emergency). Accepting this set of economic measures by employers, the Serbian government endeavored to preserve the same number of employees compared to March 15, 2021. Furthermore, Serbia's government adopted the measures targeting particular professions - health care workers by increasing wages in the health sector by ten percent, accompanied by increasing the employment in this sector, and in the profession of freelance artists by providing them additional financial assistance (ILO, 2020: 42). 
Models of initial crises responses have been mostly similar among countries. They have targeted both self-employed workers and small businesses by providing them direct, temporary financial support by way of either tax reductions (for instance in Sweden) or specific loans (in the US, Italy and Sweden) (Eichhorst, Marx \& Rinne, 2020: 377). In Serbia, the support measures have been provided for a period of three months during the state of emergency. Contrary to the comparative practice, in Serbia, a temporary Covid-19 short-time work scheme has not been applied. Serbia's failure to adopt such a measure, which is at odds with other EU countries, is questionable (Eichhorst, Marx \& Rinne, 2020: 377). A temporary Covid-19 shorttime work scheme presupposes that the state covers some percent of wage while the worker is engaged part-time or is on leave. Some countries, such as France and Germany, allow short-time work without any cost to the employer, although this is not the standard in Europe (Eichhorst, Marx \& Rinne, 2020: 378). In some countries, such as Switzerland, this measure aims to support the vulnerable workers, such as temporary, on-call workers as well as apprentices i.e., the young workers. Serbia's failure to adopt this kind of measure could be considered as the main shortcoming of the applied job retention measures in the labour sector. In the Netherlands, for instance, the government has adopted the re-training scheme for the specific category of vulnerable workers aiming job-to-job changes (Eichhorst, Marx \& Rinne, 2020: 378). Serbia, on the other side, has failed to adopt specific measures targeting vulnerable workers in the long-run. The government's failure to adopt a long-term strategy to revive the employment and labour sector in term of sustainable post-pandemic recovery is a serious shortcoming.

\section{$5 \quad$ Conclusion}

The Covid-19 pandemic has had a devastating impact worldwide on issues pertaining to health, economics and social well-being. The most developed economies of the world have recorded a negative GDP growth. The economic system of neoliberal capitalism has certainly been shaken by the pandemic. Accordingly, the Covid-19 pandemic collapsed dogmas on which rests the neoliberal doctrine, namely: individual liberty and the free market. Furthermore, this situation has demonstrated that the power of the state has not been surpassed, as the proponents of the neoliberal doctrine believed. However, there is still a high degree of uncertainty regarding the further development of the health situation and the related economic crisis, both in terms of duration and in terms of the amplitude of negative outcomes. 
It is undoubted that the global economy will not be the same after the crisis, and the same is true for the financial system and banking sector, which are integral parts of the economy (Vasić, 2020: 6).

The awareness of health and socio-economic risks stemming from the current pandemic, as well as the inevitable changes that will occur in the economic and social systems, requires the engagement of all actors - international organizations, national governments, research organizations, social partners to mitigate the effect of the crisis in order to build the new - sustainable economy. There are three key issues that policymakers in Serbia must take into account in the succeeding period. Primarily, the Serbian economy is not isolated and largely depends on economic flows in the EU and neighboring countries. Serbia conducts most of its foreign trade with these countries. The eventual deterioration of the economic situation would inevitably spill over into economic activity in Serbia. The largest percentage of investments come from EU countries, which are a significant factor in the development of the Serbian economy. Secondly, the economic crisis caused by the Covid-19 pandemic does not have the same impact on all economic sectors. As opposed to the telecommunications and construction industries, which were not severely impacted, the accommodation, transport, retail and tourism sectors have faced serious problems. Thus, it will be necessary to define sector-based measures to mitigate the decrement in economic activity in the industries that are most affected, and targeting, particularly, vulnerable workers. The measures adopted so far represent so-called ad hoc measures provided on a case-by-case basis, neglecting the long-term effects of the crisis on economic activities and, consequently, on employment and labour. So, a comprehensive and data-reliable assessment had to be conducted in order to propose the recovery strategy which will help tackle the sustainable development goals, towards green growth and the circular economy.

This type of crisis has two phases, the actual epidemic phase and the recovery phase. However, given the risk of multiple successive waves of Covid-19, these two phases can be repeated. In the first phase, it is necessary to provide immediate support, especially for sustainable companies to be able to retain human resources. In the second phase, the policymakers should offer both financial and advisory support to enable entrepreneurs to adopt a new business model. In that sense, the entrepreneurs and companies will have to adjust their business models to the "new normality". In this regard, access to sources of financing should not only refer to overcoming 
liquidity problems, but also to providing sufficient amounts of funds to invest in new technologies and innovations.

\section{Acknowledgments}

This paper was written as part of the 2021 Research Program of the Institute of Social Sciences with the support of the Ministry of Education, Science and Technological Development of the Republic of Serbia.

\section{Legislation, Acts, Regulations and Court Decisions}

Commission for State Aid Control of the Republic of Serbia, (2020). Available at: http://www.kkdp.gov.rs/eng/o-nama.php, (10 March 2021).

International Labour Organization (ILO) (2020) COVID-19 and the World of Work: Rapid Assessment of the Employment Impacts and Policy Responses, SERBLA, retrieved from: https://www.ilo.org/budapest/what-we-do/publications/WCMS_749201/lang-en/index.htm (10 September 2021).

Law on State Aid Control, Official Gazette of the Republic of Serbia, no. 51/09.

Law on State Aid Control, Official Gazette of the Republic of Serbia, no. 73/2019

Regulation on the Rules and Procedure for State Aid Granting, Official Gazette of the Republic of Serbia, no. $13 / 10$.

Regulation on the Rules for State Aid Granting, Official Gazette of the Republic of Serbia, no. 13/10, 100/11, $91 / 12,37 / 13,97 / 13$ and 119/14.

Rulebook on Methodology for Drafting Annual Report on Granted State Aid, Official Gazette of the Republic of Serbia, no. 3/11.

The Decree on Amendments to General Revenues and Receipts, Expenditures and Expenses of the Budget of the Republic of Serbia for 2020 in order to eliminate harmful consequences due to Covid-19 disease caused by SARS-CoV-2 virus, Official Gazette of the Republic of Serbia, no. $60 / 2020$.

The impact of the COVID-19 pandemic on jobs and incomes in G20 economies, ILO-OECD paper prepared at the request of G20 Leaders, Saudi Arabia’s G20 Presidency, 2020.

The Treaty on the Functioning of the European Union, Official Journal of the European Union, C202/47, 7.6.2016

\section{References}

Baldwin, R. \& Weder di Mauro, B. (2020) Introduction, In: Baldwin, R., Weder di Mauro, B. (eds.) Economics in the time of Covid-19 (London: CEPR Press), pp. 1-30.

BDKadvokati, (2020) Serbia has new State Aid Control Act. Available at: https://bdkadvokati.com/serbia-has-new-state-aid-control-act/ (23 February 2021.

Beck, T. (2020) Finance in the times of coronavirus, In: Baldwin, R., Weder di Mauro, B. (eds.) Economics in the time of Covid-19 (London: CEPR Press), pp. 73-77.

Eichhorst, W., Marx, P. \& Rinne, U. (2020) Maneuvering Through the Crisis: Labour Market and Social Policies During the COVID-19 Pandemic, Intereconomics, 55(6), pp. 375-380.

Fana, M., Torrejon Perez, S. \& Fernandez-Macias, E. (2020). Employment impact of Covid-19 crisis: from short term effects to long terms prospects, Journal of Industrial and Business Economics, (47), pp. 391-410.

Gecić Law (2020) Uticaj pandemije virusa Covid-19 na privredu: mere državne pomoći, retrieved from: https://www.coronavirus.geciclaw.com/sr/uticaj-pandemije-virusa-covid-19-na-privredumere-drzavne-pomoci/ (26 February 2021). 
Loayza, V. N. \& Pennings, S. (2020) Macroeconomic Policy in the Time of Covid-19: A Primer for Developing Countries, Research \& Policy Briefs, (28). World bank Group, pp. 1-9.

Marjanović, D. \& Đukić, M. (2020) Ekonomske mere za ublažavanje posledica Covid-19, In: Mitić, P., Marjanović, D. (eds.) Black Swan in the world economy 2020 (Beograd: Institut ekonomskih nauka), pp. 91-105.

Martin, V. (2020) Odgovor monetarne i fiskalne politike na Covid-19 u Srbiji, Bankarstvo, 49(2), pp. 70114.

Milić, S. \& Anđelković, N. (2021) Ekonomske mere protiv pandemije u EU, In: Đorđević, B., Kostić, D., Simonović, A. (eds.) Regional Development and Cross-Border Cooperation (Pirot), pp. 381-395.

OECD (2020) The territorial impact of COVID-19: Managing the crisis across levels of government.

Peterson, O. \& Thankom, A. (2020) Spillover of Covid-19: Impact on the Global Economy, MPRA Paper, (99850), pp. 1-27.

Tasić, S. (2020) Pandemija i druge krize: sličnosti, razlike i lekcije, In: Mitić, P. \& Marjanović, D. (eds.) Black Swan in the world economy 2020 (Beograd: Institut ekonomskih nauka), pp. 82-90.

Udovički, K. \& Medić, P. (2021) Uticaj COVID-19 krize na zaposlenost: Fokus na ranjive kategorije (Beograd: Tim za socijalno uključivanje i smanjenje siromaštva Vlade Republike Srbije).

Vasić, V. (2020) Bankarski sektor u borbi za ublažavanje efekata pandemije. Bankarstvo, 49(2), pp. 4-9. 